\title{
AUTOS, CAMINOS Y CLASES MEDIAS EN LOS AÑOS VEINTE. ENTRE EL ÍCONO CUZQUEÑO Y EL DESARROLLO DEL TURISMO NACIONAL
}

\author{
CARS, ROADS AND MIDDLE CLASSES IN THE 1920 S. \\ INBETWEEN THE CUZCO ICON AND \\ THE NATIONAL TOURISM DEVELOPMENT
}

Fernando Armas Asín

Universidad del Pacífico, Perú

\section{RESUMEN}

El estudio analiza la historia del turismo en el Perú en la década de 1920. Trabaja su desarrollo en el sur andino peruano basado en el turismo receptivo, la acción de las empresas y la elite regional. Sostiene que el turismo nacional se desarrolló a partir de la labor del Touring Club Peruano y la obra de caminos emprendida por el gobierno de A. B. Leguía; plantea, además, que es a partir de esa década que se puede verificar las primeras políticas públicas con relación al turismo.

Palabras clave: Cuzco, Estado, Oncenio, raids, Touring Club Peruano.

\begin{abstract}
This study analyses the history of peruvian tourism in the decade of 1920: Its development on the andean south region based on receptive tourism, as well as the private companies actions and the regional elites. It holds that National tourism developed from the work of Touring Club Peruano and the road works undertaken during the government of President A.B. Leguía. Lastly, it proposes that it is in this decade that the first public policies related to tourism can be verified.
\end{abstract}

Keywords: Cuzco, State, Oncenio, raids, Touring Club Peruano.

Este es un artículo Open Access bajo la licencia Creative Commons Atribución-NoComercial-Compartirlgual 4.0

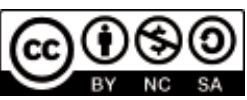


En este artículo exploraremos los cambios que acontecen en el desarrollo del turismo hacia los años veinte, tras la Primera Guerra Mundial. Analizaremos la importancia de los automóviles y los caminos para su desarrollo, tomando en cuenta, tanto los espacios a recorrer como el entender quiénes pueden hacerlo. Hablaremos de las clases medias y su interés por conocer y recorrer el país así como de los significados que sobre ellos van adquiriendo. Seremos testigos entonces de un cambio en el llamado turismo interno, rompiendo la lógica del siglo XIX, en que había estado circunscrito básicamente al ocio de la élite local. De igual manera, veremos cuál fue la importancia del Estado en esta dinámica. Estados y clases medias eran dos actores hasta ese momento invisibilizados. Por último, no dejaremos de hablar del turismo receptivo y su relevancia, particularmente para el sur andino.

\section{La bicicleta, el auto y el turismo en el hemisferio norte y en América Latina}

Una de las características del advenimiento del siglo XX fue que el turismo se hizo menos dependiente -al menos para las clases altas en Europa y Estados Unidos- del ferrocarril o los barcos de costas para facilitar el traslado a ciertos lugares de interés. La invención de la bicicleta a finales del siglo XIX revolucionó las prácticas del turismo, y los que la poseían lo veían como una distinción que les permitía viajar a cualquier lugar. En 1890 se crea el Touring Club de Francia y los británicos crearon The British Touring Club. El Touring Club Ciclístico Italiano se funda en Milán en 1894 según el modelo del Cyclist’s Touring Club, ideado para promover el turismo en bicicleta, convertido en el año 1900 en el Touring Club Italiano, con la ampliación de la actividad al turismo en automóvil y en tren. Fueron todas ellas organizaciones que con sus comités provinciales intervinieron, a lo largo y ancho de sus respectivos países, promoviendo los viajes, apoyando la construcción de carreteras, caminos y el uso intensivo de diversos vehículos de traslado de personas. Los aficionados al turismo organizaron la primera carrera ciclista del Tour de France en 1903, que ayudó igualmente a hacer conocer el país.

Por su lado el automóvil fue el otro vehículo usado por las clases altas, que también facilitó al traslado por las campiñas, las montañas o las costas para observar, deleitarse, y asimismo, consolidar los lugares de verano. En 1895 unas cincuenta personalidades, de las cuales la mitad eran nobles, fundaron el Automóvil Club de Francia y en 1900 se confeccionó la primera guía Michelin que ayudó a los usuarios con la divulgación de lugares donde descansar, hospedarse, comer y una descripción de los sitios susceptibles de ser visitados. En los Estados Unidos, en 1903, Horatio Jackson realizó el primer viaje en automóvil a través de todo el país, seguido luego en 1909 por cuatro amigas -entre ellas la esposa de un rico abogado, Alice Huyler Ramseyquienes en cincuentainueve días hicieron el tránsito entre Nueva York y San Francisco. En 1903 se crea la American Automobile Association y desde 1908 Henry Ford oferta su modelo T, logrando durante los siguientes veinte años colocar en el mercado 15 millones de unidades, haciendo posible que parte del sueño americano sea también tener un automóvil para recorrer los diversos lugares del país, que las carreteras -en plena construcción-posibilitaban.

Todo ello configuró un nuevo orden para las movilizaciones humanas hacia las playas, balnearios, bosques y montañas. En Gran Bretaña, desde 1910, había servicios de buses -caraván, de char à banc- que ofertaba el viaje de Eastbourne al Norte de Gales, y en Francia Deaville estuvo al alcance de los menos privilegiados. 
Antes de la Primera Guerra Mundial el turismo se había concentrado en las estaciones termales y en los balnearios marítimos de Europa, y en los Estados Unidos en estos y los parques nacionales de Yellowstone, Yosemite y el estatal de las cataratas del Niágara. La popularización del automóvil, en la década de 1920, convirtió a más regiones en accesibles y contribuyo a la formación de nuevos itinerarios turísticos. Las carreteras norteamericanas complementaron a las líneas férreas y se abrió al turismo masivo Jacksonville, St. Augustine, Tampa, Miami, Kay West o West Palm Beach. Incluso se abrieron nuevas áreas, como Coral Gables, donde se creó el moderno Hotel Biltmore, muy famoso en su tiempo. El bronceado irrumpió como un ideal para las personas expuestas al sol y ayudó al cambio del estilo de la ropa de baño. En la década de 1920 llegaron a Florida picos de 1.8 millones de visitantes anuales y el primer tren especial bronceado llegó a las playas de California en 1931.

Los norteamericanos, por otro lado, invadieron gracias a los tipos de cambios de divisas que les favorecían, Europa. No solo intelectuales como Ernest Hemingway, Scott Fitzgerald y otras figuras literarias, sino personajes de todo tipo convirtieron de sus vacaciones en Europa algo soñado. Surgió Juan les Pins como lugar de reunión de artistas de Hollywood, intelectuales o nobles; y Megève como lugar de la alta elite. Aparecieron guías como las de Frank Schoonmaker, Through Europe on Two Dollars a Day, publicado por primera vez en 1927, y reimpreso muchas veces después, permitiendo abrir Europa al turista de clase media, que llevó su gusto por la playa a Niza y otros lugares de la Costa Azul. El mediterráneo se convierte en un lugar de moda y St.-Tropez o Collioure los lugares de refugio de pintores y artistas. Los balnearios meridionales no solo serán ocupados en invierno -cuando los europeos aristócratas huían del clima invernal- sino ahora masivamente en verano. Los restaurantes y la gastronomía se desarrollaron y la compañía de neumáticos Michelin comenzó a calificar los restaurantes en 1926, para cinco años después introducir la clasificación de tres estrellas (Boyer, 2002; Gordon, 2002; Harp, 2002; Khatchikian, 2000; O’Connell, 1998; Walton, 2002).

El turismo influyó positivamente sobre la calidad global del servicio ferroviario. Mejor iluminación, calefacción, asientos acolchados, la mejora en los servicios higiénicos a bordo y de los bufés y la mayor atención dedicada al diseño de los vagones. Por último, hacia el exterior de Europa y Norteamérica, empezó en esos años la gran era de los cruceros de lujo (Giuntini, 2002, p. 112).

En América Latina el turismo procedente de Estados Unidos o Europa lentamente fue llegando a México, a través de la frontera común o a través de Veracruz; también a Cuba y Puerto Rico; o a las costas del Pacífico Sur, gracias a las compañías navieras. El turismo interno dependió mucho del desarrollo de los mercados locales y en Argentina el ferrocarril, que une prácticamente todo el territorio, permitió el desarrollo de las playas de la Provincia de Buenos Aires, mucho antes que las carreteras lograran su masificación. Si antes de 1880 los territorios entre Buenos Aires y Bahía Blanca eran considerados inhóspitos e improductivos (para la vida agraria y para la colonización), luego cambió. Se desarrolla Mar del Plata lentamente (Dadon, 2005, pp. 54-55; Pastoriza, 2002).

La creación del Automóvil Club Argentino (1904) y del Touring Club Argentino (1907) favorecieron el desarrollo turístico argentino en el siglo XX. El Automóvil Club Argentino, que al inicio de su existencia tuvo un carácter elitista, a partir de 1920 pasó a favorecer el desarrollo de la viabilidad y las actividades de excursión 
ligadas a ellas. Influyó en las autoridades para la construcción de autovías y difundió entre las capas altas y medias urbanas la importancia del viaje, del contacto con la naturaleza, además que organizó carreras de autos desde mediados de la década de 1920 que ayudaron a conocer el país. Mientras el Touring Club Argentino, que fue una institución que desde el inicio se preocupó de la viabilidad -en 1923 tenían 10 mil socios en 200 delegaciones instaladas en el país- planteó en la década de 1920 la idea de que el turismo era también un asunto de interés público, antes la institución lo consideraba parte de la esfera privada. Patrocinó desde entonces la democratización del turismo, para salir de la ciudad y gozar los aires y el paisaje. Desarrolló un fomento considerado al inicio propio del sector privado pero con ayuda complementaria del Estado, aunque luego en la década de 1930 anidó la idea de un organismo del Estado que aparte de construir vías fomente y regule el turismo (Ballent, 2005; Piglia, 2008, pp. 51-70 y 2008a).

\section{El turismo y el Perú antes de 1920}

Mientras todo ello ocurría, en el Perú el turismo mostraba, hacia 1920, este panorama: la apertura del sur andino al mundo, de la mano de las elites regionales y de la labor de la Peruvian Corporation habían permitido la existencia de una ruta turística -promovida además por las compañías navieras en la costa del Pacífico Sur (Grace Line, Steam Navigation Company y otras)- para algunos viajeros con recursos y otros interesados -misioneros, intelectuales, etc.- que llegaban al Callao y luego a Mollendo, y de allí siguiendo la ruta del ferrocarril se fueran o bien al Cuzco o bien hacia Puno, el lago Titicaca y Bolivia. Era un naciente espacio creado básicamente para el turismo receptivo. Para el turismo interno, la sierra central era prometedora. En este caso las riquezas naturales, las aguas termales, el clima del Valle del Mantaro -Tarma, Jauja- considerado saludable para el restablecimiento o curación de enfermedades, era una invitación a explorar sus posibilidades. La Peruvian Corporation promovía sus bondades a través del ferrocarril central, que permitía visitar diversos lugares para el descanso desde Chosica en adelante. Este interés de la compañía ferrocarrilera se cruzaba con el creciente excursionismo que empezaba a estar de moda entre la clase media, estudiantes y posteriormente algunos obreros de Lima.

Por último, no menos importante era el atractivo de las playas, para el descanso en verano, sobre todo de las clases altas limeñas. Estas tenían la posibilidad de habitar directamente en el balneario de Chorrillos -majestuoso con sus casonas, sus baños o las diversiones en su Casino (1896)-, o bien ir de visita en los veranos, bajando a las playas aledañas. En aquella época de Miraflores al Callao los acantilados impedían la existencia de estas, y los pocos metros donde las hubiera estaban repletos de piedras. Solo en Chorrillos había posibilidades de playas extendidas: Agua Dulce o La Herradura. La empresa del tranvía de Lima que conectaba Lima con Chorrillos a través de un túnel llegó en 1907 a La Herradura, tratando de desarrollarla como balneario, pero fracasó, y las vías quedaron abandonas, construyéndose en su lugar un camino carretero que permitió que algunas familias limeñas en sus autos llegaran al sitio. En el caso de Barranco, pronto se convirtió en un lugar de residencia de personas de clase media y de muchos extranjeros que, a diferencia de Chorrillos, mayormente residían todo el año. El interés por bajar al mar y bañarse, y no solo aprovechar los chorrillos de agua dulce que caían por los acantilados, hizo que, así como en Chorrillos, se construyan unos baños a los que se accedía por un funicular que al inicio funcionaba con un sistema de poleas. A los ya conocidos Barranco y 
Chorrillos por el sur, hay que tomar en cuenta La Punta en el Callao y por el norte Ancón, que se desarrolla intensamente, con casas de presidentes, políticos o intelectuales reconocidos, por ejemplo, la residencia de Ricardo Palma. Diversas playas cercanas se van abriendo poco a poco al descanso de los limeños.

\section{El oncenio de Leguía}

La década de 1920 está marcado políticamente por el largo gobierno de Augusto B. Leguía, el Oncenio (1919-1930). Como bien sabemos este político y hombre de negocios, que ya había gobernado el país como uno de los presidentes de la denominada República Aristocrática (1895-1919) regresa al poder con un discurso y acción marcadamente populistas. Su largo gobierno - en el cual manipula la Constitución y se comporta como un dictador típico- posee ciertas características que vale la pena reseñar.

En primer término es un gobierno que está estrechamente relacionado con los Estados Unidos, no solamente porque el país adquiere una enorme deuda externa con aquel para financiar un programa de obras públicas, por las inversiones norteamericanas que fructifican, o porque el influjo de la diplomacia norteamericana es notable entre nosotros, sino porque durante la década se nota cómo la cultura del norte penetra en los diversos ámbitos de la vida pública. El Perú en aquéllos años se adhiere a la política estadounidense para el hemisferio, y participa activamente en las Conferencias Panamericanas. En segundo término es una época donde el Estado adquiere un discurso y práctica marcadamente indigenista, por lo menos en los inicios del régimen: estableciendo el día del Indio (24 de junio), legalizando las comunidades indígenas, creando el Patronato de la Raza Indígena -un órgano consultor adscrito a la presidencia- y unas serie de actitudes que provocan que los grupos indigenistas locales tengan que redefinirse en sus discursos, entre los que apoyen este indigenismo estatal, muy propagandístico, y los que planteen más bien cambios radicales en las condiciones socioeconómicas de las poblaciones marginadas. En tercer término, esta es una época de muchas obras públicas, una actitud populista para mantener la fidelidad al régimen, por los efectos de la multiplicación de los beneficios a escala nacional.

La política de obras públicas del régimen se hace bajo el postulado de modernizar el país, enrumbarlo hacia el progreso y unir un país escasamente articulado. En esta época se construyen muchas infraestructuras en el ámbito nacional y en Lima. En lo primero, el programa de obras viales será esencial. Mediante la dación de la ley de conscripción vial (1920), que establece que las poblaciones beneficiadas contribuyan con trabajo gratuito en su desarrollo, se da inicio a la reconstrucción, mejoramiento o construcción de una serie de vías que van enlazando los distintos lugares del país. Como veremos, no solamente será el enlace de casi la mayor parte de pueblos de la costa, mediante la llamada carretera costanera, de Tumbes a Moquegua, sino además la construcción de una serie de vías en la sierra. Aunque hacia 1930 muchas obras quedaron inconclusas, debido a la crisis económica que marca el final del régimen, y muchas áreas vitales del norte, centro y sur no se habían terminado de enlazar, sin embargo, el avance fue notable, casi dieciocho mil kilómetros de caminos habilitados. Se complementan estas obras públicas de ámbito nacional con un programa de obras de irrigación en la costa peruana, algunas de las cuales llegaron a concluirse.

En el ámbito urbano-limeño las obras públicas tuvieron como telón de fondo los festejos por el Centenario de la Independencia (1921) y de la batalla de Ayacucho (1924). Para la celebración del Centenario se invitaron 
a numerosas delegaciones de países amigos -resaltó la argentina, que llegó en dos barcos, previa escala en Mollendo donde aprovecharon para visitar Arequipa, que también recibió a la delegación boliviana, de paso a Lima (Loayza, 2016, pp. 145-174)-, hubo celebraciones públicas e inauguraciones de monumentos y otras obras de embellecimiento urbano. Luego se repitió lo mismo con el Centenario de la batalla de Ayacucho, e incluso una delegación que asistió al Tercer Congreso Científico Panamericano visitó Chanchamayo (La Serna \& Chaumeil, 2016, p. 31).

En las celebraciones de 1921, con tantas delegaciones invitadas, hubo dificultades para su alojamiento. Acostumbrados los pocos turistas que llegaban al Callao a bajar de los barcos, visitar la ciudad para regresar a sus camarotes, no había una oferta real de hoteles con las comodidades requeridas. En los festejos algunos se alojaron en casas de familias y otros en los hospedajes disponibles -hoteles Maury, Francia e Inglaterra, Central, Americano, Europa, París, Comercio, Italiano, entre otros- sin las facilidades higiénicas y de equipamiento moderno, solo preparados para recibir a hombres de comercio y a algunos otros dispuestos a sufrir las incomodidades. Se vio la necesidad de contar en Lima con un hotel de primera categoría (El Comercio, 9-IV, 1924).

Por ello, para la celebración de 1924, en que además se celebraba simultáneamente el Tercer Congreso Científico Panamericano, la Segunda Conferencia Panamericana de Mujeres y la Primera Conferencia Panamericana para la Uniformidad de las Especificaciones, se quiso eliminar ese problema. El gobierno cedió en enfiteusis -por 99 años- el terreno de cuatro mil metros cuadrados donde se había levantado la Exposición Internacional Industrial (El Palacio de Cartón), que había devenido en inservible, y en donde en 1919 se quiso construir ya un hotel -el Pizarro- tomando en cuenta los festejos del Centenario. El terreno fue cedido al Sindicato Wiese, una empresa inmobiliaria, cuyo presidente era el empresario Augusto N. Wiese y que tenía como socio a su hermano Fernando, para que construyera un hotel: el Gran Hotel Bolívar. La concesión de la obra permitió al Sindicato organizar la Sociedad Anónima Grand Hotel Bolívar y disponer de 500 mil libras peruanas para la obra. El nombre parece lo sugirió el mismo Leguía, pues se pensó al inicio en Ayacucho, por el aniversario, pero su traducción (rincón de los muertos) no parecía muy agradable. Leguía, cuentan, dijo con referencia a la Plaza a la que miraba el edificio que «frente a un San Martín no puede haber sino un Bolívar». El arquitecto de la obra fue Rafael Marquina, exponente de la arquitectura neocolonial, quien utilizó ampliamente el mármol en el edificio de cuatro pisos pero pensado para posteriores ampliaciones, obra de estilo renacentista francés que no desarmonizó con la Plaza San Martin. La constructora fue la norteamericana Fred T. Ley y estuvo listo el 20 de noviembre de 1924 (Ahora, 1982; Dargent, s.f., pp. 1-6; Orrego, 2014, pp. 160-161).

Con sus doscientas habitaciones con baño propio, finos muebles y preciosa decoración en el hall, salón y salas, comedor principal y comedores secundarios, con los dos primeros ascensores que existieron en el país, fue inaugurado el 6 de diciembre, tres días antes del centenario de Ayacucho. Tenía un servicio de lavandería propio y los restaurantes eran atendidos por un maître, el señor Tschopp, que lo había sido del hotel Ritz de Londres y del Palace de Ginebra. Para la preparación de los alimentos y supervisión de las cocinas se contrató a un chef suizo, el señor Haenggi, con experiencia en los hoteles Palace de Lausana y Ritz de Madrid. Tras el centenario la administración del Gran Hotel Bolívar fue entregada a la Negociación Visconti \& Velásquez, 
que concesionaba el hotel Maury -de propiedad de la familia Bertolotto- y con experiencia en el ramo de restaurantes. Ellos contrataron a la orquesta The Pyramo's para amenizar el servicio de almuerzo y cena en el comedor principal, pudiendo bailar los que quisieran en el Lieux Danzant que se había condicionado. Los precios del comedor era de cinco soles tanto el almuerzo como la cena. Los precios de las suites con dormitorio, sala, escritorio, baño y vista a la calle más pensión completa eran de tres libras por persona; de dos y media las que no contaban con escritorio y de dos libras las habitaciones simples con baño. Había servicio telefónico desde la centralita del Hotel para comunicarse con Miraflores, Barranco, Chorrillos y el Callao. En la habitación 312, que era una suite, hubo una radio desde fines de la década. En los salones, aparte de los dinners, concours y tés blancos, se presentaban exposiciones de arte pictórico, textil y fotográfico de antigüedades peruanas, de joyas, así como la realización de desfiles de moda. Al año Visconti \& Velásquez dejó la administración del hotel y los Wiese lo tomaron a su cargo (Ahora, 1982; Dargent, s.f., pp. 6-9; El Comercio, 4-I-1925).

Desde el punto de vista del turismo era «el mejor hotel de Sud-América», considerado «el Centro ideal para turistas» y el Hotel procuraba publicitarse de este modo considerando tanto al visitante nacional como al extranjero (Touring Club Peruano, 1925, I-3, pp. 53-58). Para 1933 la deuda en que el Sindicato incurrió para realizar la empresa había quedado saldada, levantando su hipoteca y pagando los bonos emitidos. Como decía la revista Mundial, el hotel estaba llamado «a tener honda repercusión en la vida de la relación internacional, comercial y social» del país (Mundial, 12-XII-1924).

En una ciudad en expansión, otro hotel construiría el Sindicato: el Country Club de San Isidro. La idea fue establecer un hotel alejado del bullicio de la ciudad, un remanso en lo que había sido la antigua hacienda San Isidro ahora, gracias a la Avenida Leguía, incorporada a la ciudad. La construcción del hotel se inició en 1925 y fue encargada a la Foundation Company de Nueva York. El edificio, totalmente hecho de cemento armado y ladrillo, responde al estilo español californiano, que le da una gran amplitud de terrazas y que se beneficia de la vista del campo de golf de nueve hectáreas que se extiende frente al edificio y que fue inaugurado el 28 de mayo de 1924 «para trasladar allí las actividades de los golfistas que hasta ese momento habían jugado en los terrenos colindantes con el Campo de Marte» (Dargent, s.f., pp. 13-15).

Contaba el hotel con una amplia piscina para que los socios, y posteriormente los pasajeros, gozasen de ella en los meses de verano; contando también con un amplio campo de polo para quienes se dedicasen a ese deporte, «adosado al cual había caballerizas, picaderos y todo cuanto era necesario» (Dargent, s.f., p. 15).

El gerente del Hotel Bolívar, Arthur Elminger, ante el éxito del Bolívar propuso al Sindicato adquirir el Country Club e incorporarlo como anexo al Bolívar, de modo que en los meses de verano los pasajeros tuvieran a su disposición un ambiente más fresco, rodeado de jardines y piscinas. Elminguer fue administrador de ambos hoteles y luego Edward Koch, alemán que se desempeñó antes como contador en la casa Wiese. Luego sería administrador el hotelero francés Jean Magnet (Dargent, s.f., pp. 13-15). 


\section{Las narrativas locales y la consolidación del Cuzco para el turismo receptivo}

Mientras ello ocurría, en el Sur, las elites intelectuales, por distintas vías, ponían en perspectiva el pasado y presente andino como esencial en la constitución patrimonial del Cuzco. Los Andes eran el patrimonio del Perú y la raza indígena llamada a nuclear el país, lo cual implicaba rescatar su dimensión histórica, ancestral, base de la nueva sociedad a construir. Los diversos trabajos de L. E. Valcárcel, desde su tesis universitaria juvenil hasta Del Ayllu al Imperio (1925) y De la vida incaica. Algunas captaciones del espíritu que la animó (1925) están teñidos de un fuerte sentimiento de añoranza y de figuras simbólicas necesarias para la construcción retórica. En ellos se imprimió con fuerza el romanticismo por el Cuzco, el centro, ombligo del mundo, madre de la cultura andina. «iCuzco libertador! (...) siempre hacia ti los hombre vuelven sus ojos» exclamaba extasiado «eres como el cuerpo y el alma de este pueblo» (Valcárcel, 1925, p. 11). El Cuzco simbolizaba todo lo que era auténticamente peruano, mientras Lima era la moda europea. En los años 20 Valcárcel se aleja de ideas románticas incaístas o versiones basadas en un país crisol de sus distintas raíces, para publicar Tempestad en los Andes (1927), donde ratificaría y ampliaría sus concepciones sobre la vertiente andina como columna vertebral del nuevo país.

No fue el único, por cierto, en ir contribuyendo a la construcción del patrimonio cuzqueño. José Uriel García, planteaba que el «neo indio», el mestizo, había impuesto contra la cultura hispánica su propio arte, de orígenes andinos. La imagen de la virgen de la Iglesia de Belén, anotó, es claramente una mujer mestiza; y la del Señor de los Temblores, un campesino. La tradición preincaica, incaica y colonial se funden en una sola en la ciudad del Cuzco, como puede ser la arquitectura de la Catedral, los conventos cuzqueños, las manos artesanas indígenas que han hecho gran parte de las obras plásticas, la fiesta del Corpus Christi donde hay continuidad con los antiguos raimis que celebraba la ciudad incaica. Lo plantea claramente en La Ciudad de los Incas (1922) como en la Guía histórica-artística del Cuzco (1925), en coautoría con Luis E. Valcárcel, ambas insertas con muchas postales de los estudios fotográficos de la ciudad. Mientras el puneño Emilio Romero, creía que el Cuzco escondía dentro de sí facetas no exploradas de la cultura andina. En diversos artículos, como en su libro 3 Ciudades del Perú (1929), se maravilló de la obra misionera colonial en Cuzco, Copacabana o la Isla del Sol en el Titicaca, intensificando la religiosidad campesina y evocando las ceremonias incaicas. La religiosidad cuzqueña, «tiene una sensualidad extraña, soberbia, voluptuosa», impregnada de los mismos sentimientos que tenía cuando bailaban en «éxtasis místico» en la fiesta del Inti Raymi. Hasta los templos tienen el sello original de los indígenas, del poderoso pasado incaico. En su descripción de la Catedral del Cuzco, lo subrayó: «Las murallas son hispánicas, pero la tierra, la piedra negra, es india. (...) Por las murallas trepan, en columnas retorcidas, espíritus extraños, que extravían la imaginación; pero, por las claraboyas, penetra desafiante el sol que alumbró el Tamputtoko. Sus bóvedas pétreas y sus pilares y gárgolas se convierten en símbolos indígenas ante el paisaje cuzqueño» (Romero, 1929, pp. 24-39).

Así, los indigenistas, en su construcción retórica del indio, terminaron por construir el patrimonio andino cuzqueño y por extensión del sur andino: en 1926 José Frisancho retrató poéticamente las procesiones de Semana Santa del Cuzco; José Uriel García recreó la procesión del Corpus Christi del Cuzco colonial; y Emilio Romero hizo un contraste entre las procesiones religiosas de Cuzco, Arequipa y Puno (Frisancho, 1931; La Sierra, 1927, pp. 19-22; Romero, 1929, pp. 90-101). 
Lo ocurrido con la expedición de Hiram Brigham y la furia que se desató entre los intelectuales cuzqueños es un hecho que termina de interiorizar la idea de que el Cuzco es un lugar sagrado y antiquísimo que no solamente hay que enunciar sino también cuidar, frente a buscadores de tesoros y otros aventureros extranjeros que desean ultrajar el país. Gabriel Cosio publica en 1912 «Una excursión a Macchupiccho, ciudad antigua» con un claro interés por la preservación (Cosio, 1912). En 1913 se funda el Instituto Histórico del Cuzco, para detener la depredación y estimular una memoria de pasado y del valor tradicional del Cuzco. Lo integran Valcárcel, Uriel García, José Gabriel Cosio, el canónigo Juan Antonio Casanova, José Lucas Caparó, Cosme Pacheco, Félix Cosio, etc. Desde entonces hubo la necesidad de afincar mejor la puesta en valor de los bienes materiales, mediante diversos estudios académicos y de divulgación general. La tesis doctoral de Felipe Cossío del Pomar (1922), sirvió para actualizar el estudio de las imágenes coloniales, integrando a artistas plásticos desconocidos y sus obras a la gloriosa estética cuzqueña y del país. Este registro de obras pictóricas cuzqueñas coloniales serviría al autor para probar las condiciones históricas que han convertido al Cuzco en el centro de resurgimiento del pasado esplendor. A él se debe que la serie de la Procesión del Corpus, albergada en la parroquia de Santa Ana, pase a convertirse en alegorización del mestizaje artístico cuzqueño. En la misma línea hay que entender a La ciudad de los Incas (1922) de Uriel García, Cusco Histórico y monumental (1924) de José Gabriel Cosio, que en Lima se publicó como Cuzco, the historical and monumental city of Peru: travelerśguide, dirigido al público visitante extranjero; Guía Histórico-Artística del Cusco (1925) de Uriel García y Luis E. Valcárcel; y Guía del Cuzco. La meca de la América del Sur (1924), del exrector de la universidad Alberto Giesecke, tan interesado en promocionar este espacio territorial como uno de interés turístico.

Aunque parte de estos textos ya se habían publicado antes, solo desde 1920 se articularon como discursos orgánicos de difusión popular, gracias también a los recursos fotográficos, que en forma masiva empezaron a usarse entonces (López, 2004, pp. 231-305 y 343). La difusión del Cuzco y el sur andino andino respondió pues a la propia consolidación del lugar como un icono cultural. En el contexto del Oncenio el discurso indigenista se vuelve común en la mano de los políticos, de diversas instituciones sociales y de artistas.

Cuzco en esos años era todavía una ciudad que dependía, para visitarla, del ferrocarril. En 1915 de los únicos cuatro automóviles que circulaban, uno era de Luis. E. Valcárcel, que se daba cuenta de lo importante del viajar, aunque sea a cortas distancias. Daba la movilidad una nueva dimensión de los lugares a visitar. De hecho él solía ir constantemente a Sacsayhuamán en coche (López, 2004, pp. 258).

La difusión de guías y las propuestas de las mismas estaban en pleno proceso de innovación. Desde inicio de siglo existen los estudios de Miguel Chani y de José Gabriel Gonzáles, formados por fotógrafos extranjeros en la ciudad. Luego se incorporan los estudios de Juan Manuel Figueroa Aznar y de Martín Chambi, este último formado en Arequipa en el estudio de Max T. Vargas. Entre 1900 y 1910 pasaron por Cuzco Fernando Garreaud, Luis Gismondi y Max T. Vargas fotografiando sitios arqueológicos, coloniales, las calles de la ciudad y ayudando a promover una imagen del lugar. Va a ser gracias a los fotógrafos, que al grabar, aparte de las familias cuzqueñas, escenas de la vida material urbana, monumentos o a tipos indígenas, se contribuya a una valoración local de lo que se posee. Como hay demanda de los visitantes se venden dichas fotos como postales y es un buen negocio para los estudios. En el marco del Centenario, en 1921, apareció la Guía General del 
Sur del Perú, con ochenta fotos, «postales incaicas», para su venta a los viajeros. Para 1924 ya se ofrece al turista otro archivo visual cuzqueño en forma de tarjetas postales. La Guía General del Perú es vendida en la librería de Héctor Rozas, y también postales y series de fotos sobre el Cuzco hechos por los fotógrafos Rozas, Miguel Chani, Manuel Figueroa Aznar, J. Chambi y José Gabriel Gonzáles. La de Chani es una colección de ochenta vistas distintas. Alberto A. Giesecke hizo la Guía del Cuzco. La Meca de América del Sur, delicioso documento muy bien redactado y ameno. El folleto apareció primero en el Mercurio Peruano y la Peruvian Corporation -propietaria del ferrocarril sur andino- lo usó en su folleto promocional para fomento del turismo, The Land of the Incas. Veintiséis páginas con textos y fotos, estas últimas con planos al aire libre e imágenes de casi todas las iglesias visitables de la ciudad.

El texto hizo hincapié en el pasado inca y colonial del Cuzco. Contuvo una guía de hoteles, desde Mollendo, por Puno y Sicuani, hasta llegar a la ciudad imperial. Allí anotó, por ejemplo, tres lugares de descanso: la Casa del Almirante, a una libra diaria; el Hotel Colón, en el Cabildo a cinco soles; y el Petit Hotel en el Portal de Escribanos. Anotó también la posibilidad de tomar el té en el Maxim (en el Hotel Colón), y presentó un recorrido de la ciudad (City Tour): la Plaza de Armas con la Catedral y la iglesia de la Compañía; la Plaza del Cabildo, La Merced y San Francisco; en otra dirección, Koricancha; y en otra Santa Catalina o el Palacio Arzobispal. Igualmente anotó libros de interés para leer: las Tradiciones y Leyendas Cuzqueñas de Matto de Turner, los Apuntes de la Historia del Cuzco, de José Gabriel Cosio, La ciudad de los Incas de Uriel García, y la guía general del sur del Perú, editado por el librero Héctor Rozas. Para llevarse souvenirs, recomendó asimismo comprar fotos y postales en la librería de Rozas y en los estudios fotográficos de Chani, Figueroa Aznar, Gonzáles y Chambi. Si se deseaba comprar «antigüedades», recomendaba acudir a algunos anticuarios, aunque «generalmente, hablando, se puede aconsejar al turista pedir también al sirviente del hotel que mande traer objetos» (Giesecke, 1924, p. 14).

Recomendaba asimismo hacer el circuito externo a la ciudad, por Pisac «y dejando la bestia con el Gobernador [se puede] pedir un indio y si es posible, otro caballo, para subir por el pueblo de Pissacc». Luego de recorrer el Valle Sagrado se podía terminar en Machu Picchu. Si se deseaba visitarlo, recomendaba leer antes el libro de Hiram Bingham, Inca Land (New York, 1922), y los números de The National Geographic Magazine de abril de 1912 y mayo de 1916, con noticias del lugar monumental. Dice que en el sitio no hay donde pernoctar, pues solo hay hoteles en Urubamba y Ollantaytambo, pero «se puede alojar en casa del Gobernador o el cura y aún en algunas parroquias» cercanas (Giesecke, 1924, p. 16). Se nota en toda la guía, que sigue el modelo de las guías norteamericanas. Anota Giesecke que desde 1921 -su guía es de 1924- el turismo va en aumento, gracias a que entre los últimos acontecimientos, como las celebraciones por el Centenario de la Independencia, en Lima, se permitió a algunos invitados trasladarse luego al Cuzco. El ve el enorme potencial turístico de la ciudad y región, la cual llama «Roma de la América del Sur, Meca del turismo de toda América». Interesante apreciación, aunque notamos en su material todavía una ausencia de otros lugares de interés más allá de los mencionados, por ejemplo, no incluye las iglesias al sur de la ciudad -Oropesa, Andahuaylillas, Huaro-.

Tras Giesecke, la construcción del patrimonio y turismo cuzqueño, tuvo otro hito de consolidación en las celebraciones por el IV centenario de fundación española de la ciudad del Cuzco, en 1934. Entonces Rafael 
Larco Herrera editó un libro de homenaje a la ciudad Cusco, Histórico. Homenaje a la ciudad de todos los tiempos en el cuarto centenario de su fundación española (Larco Herrera, 1934). Incluyó allí quinientas fotos de las colecciones de Martín Chambi y Manuel Figueroa Aznar, con textos de Luis E. Valcárcel y Carlos Ríos Pagaza. Una descripción de la ciudad y la región con un interés muy claro de perennizar para siempre este icono. La cantidad de 186 fotos fueron destinadas para hablar visualmente del Cuzco prehispánico y 77 para hablar de su símbolo más seguro: Machu Picchu. Simultáneamente la Comisión Central de Propaganda y Turismo del IV Centenario -presidida por el maestro Luis E. Valcárcel-, editó la guía turística Cusco, capital arqueológica de América, con fotos igualmente de Manuel Figueroa Aznar y otros maestros cuzqueños, bajo el cuidado editorial y redacción de textos del mismo Valcárcel. Un cuadernillo de cuarenta páginas de buen papel, descripción amena del Cuzco inca y colonial, con una selección de fotos y un recorrido por los principales sitios de interés (Valcárcel, 1934).

Estos libros y las imágenes fijaron el Cuzco, permanente, incaico y colonial, aunque mostraron una clara predilección por lo prehispánico, esencia de la naturaleza del paradigma. La fascinación por el Cuzco creció con los años y el icono adquirió vida propia. El Cuzco impactó incluso a limeños que se sintieron atraídos por él, como por ejemplo, Luis Humberto Delgado, quien a inicios del treinta miró como Machu Picchu estaba ya incorporado al patrimonio regional y asimismo las iglesias al sur de la ciudad (Delgado, 1935). Se constaba entonces que el número de visitantes, que llegaban a través del ferrocarril del sur, iba en aumento hacia la ciudad del Cuzco. Aunque en un inicio pocos se atrevían a ir por los caminos escarpados hacia Machu Picchu. Tras una integral limpieza en 1934, por la comisión de celebración del IV Centenario, la llegada del ferrocarril a Machu Picchu, así como la apertura de una carretera, permitió que fluyeran mas visitantes desde 1935.

Cuzco se abrió paso a la modernidad, de la mano de sus elites y las empresas, y un producto se fue asentando en el imaginario mundial, medio indigenista, romántico y esotérico. Se fue pues labrando una visión para el consumo internacional. Como dijo exaltada la turista Marisabel Pinilla en 1928: «[es un] efecto místico y fascinador, evocativo de cosas vividas, que el paisaje y las piedras del Cuzco producen en el viajero» (Pinilla, 1928, p. 7).

\section{El Touring Club Peruano (TCP) y el turismo nacional}

Para mediados de los años veinte, en el contexto de construcción de caminos y un creciente número de vehículos automotores -en un escenario sudamericano de difusión de las entidades que fomentaban los viajes y el descanso a través del uso de diversos vehículos- es que se fundó el Touring Club Peruano.

En enero de 1924 el Rotary Club contempló la necesidad de esta institución que «fomentara el turismo como medio para conocer y hacer conocer el Perú», encomendando a Edmundo Marino Tabusso la formación del Touring Club. Se partía del reconocimiento que se había hecho mucho por impulsar el trazado de caminos, y con optimismo observaban que las carreteras en construcción romperían el centralismo y unirían el país fomentando su recorrido y el turismo. El nacimiento de la institución ocurrió el 20 de mayo de 1925, siendo electo presidente Edmundo Marino Tabusso y prosecretario Eduardo Dibós. En el acta de fundación se planteó 
como objetivos el fomento de la construcción y conservación de vías y del uso de los medios de turismo: automovilismo, ciclismo, volación, yatching, alpinismo, camping, etc.; también se plantearon publicar guías, mapas y monografías; preparar itinerarios turísticos y organizar viajes; difundir en el extranjero «El conocimiento de los atractivos turísticos del Perú»; y publicar una revista (TCP, 1925, I-1, pp. 9-20).

Es importante subrayar que, a diferencia de otros países, aquí se funda un Touring Club pero no un organismo paralelo, el Automóvil Club -véase el caso de países europeos y de América Latina donde se crearon estos organismos paralelos y diferenciados (Piglia, 2008)-. Seguramente debido a que en su origen, vinculado al entusiasmo que la construcción de caminos despertaba, el fomento de los caminos y los viajes fue prioritario. Lo cual no quiere decir que el fomento del automóvil no haya estado entre sus objetivos, pues diversos socios -inicialmente de sectores altos- poseían uno. Pero al ser un Touring Club y estar unidos por principios más amplios, permitió -así como en Argentina- que acá el número de socios creciera rápidamente en los diversos lugares del país donde se formaba un núcleo del Touring, pues no era requisito tener un auto. Al año siguiente de su fundación se enorgullecían que no solo contaban con una revista periódica del mismo nombre sino que eran más de dos mil socios por todo el país. En 1928 eran 5468 socios. Sus delegados estaban por ciudades y regiones importantes, ayudando a la formación de estos núcleos, como Arístides Guillén de Ayacucho, Luis Dibós de San Vicente de Cañete, Salvador Boza de Imperial de Cañete, Antonio Camprubí del Cuzco, Andrés Denegro de Lomas, etc. (TCP, 1925, I-1, p. 20; 1928, IV-35, p. 38). La expansión hacia las clases medias fue notable. Contaban con sus oficinas centrales en el edificio Italia, número 205.

El entusiasmo por la obra vial emprendida motivaba al Touring y a su revista, recordándoles a sus socios lo que se estaba haciendo: la carreteras de Trujillo a Quiruvilca, de Lima a Canta, de Huancayo a Ayacucho (La Mejorada), de Cerro de Pasco a Huánuco, de Coracora a Chala, de La Oroya a La Merced, de Abancay a Ayacucho, de Camaná a Quilca, etc., gracias a la ley de conscripción vial. En 1925 había 7473 kilómetros de caminos, 5473 entre buenos y transitables, el resto en construcción. Dos años después 10643 km de caminos y 8687 en construcción, y en 1929 había 14892 kilómetros en tráfico y 18599 en construcción (TCP, 1925, I4, p. 68; 1927, III-33, p. 7; Zapatel, 1929, p. 142). Incluso el gobierno, que veía con simpatías a la organización, le había concesionado la construcción de un camino de Lima a Chosica, pues así participaría en el fomento vial y además abriría un lugar prometedor al turismo -que todavía dependía únicamente del ferrocarril para su desarrollo- (TCP, 1925, I-1, pp. 13-15 y 69).

Gracias a Andrés Dasso, un entusiasta de la aventura en automóvil, y con el apoyo decidido de la Comisión de Automovilismo del Touring, se impulsaron los primeros grandes viajes de exploración, denominados raids, que tenían como fin abrir trochas hacia diferentes zonas del Perú, que luego sirvieran como trazos para carreteras o para precisar los ya existentes. También por cierto permitían conocer rutas turísticas, medir tiempos, detectar problemáticas naturales a las que se enfrentarían los conductores, etc. Las primeras incursiones, a cargo de los socios de cada localidad, fueron a lugares cercanos, luego se aventuraron a lugares lejanos y de no fácil acceso.

Por ejemplo, de Lima partieron excursiones a Chilca, Huaral, Lurín, Huacho, Tarma, y en ese año de 1925 el Touring auspicia uno bastante numeroso -en varios autos- a La Merced, para los miembros del Congreso 
Científico Panamericano reunido en la capital -anteriormente el socio Roberto Lama, había hecho uno exploratorio de La Merced a Lima (Variedades, 20-XII, 1924)-. Otros socios hacían lo mismo, como Camprubí del Cuzco que enlazó en su coche Cuzco con Sicuani. Pronto se aventuraron a raids a lo largo del litoral, aprovechando las trochas, sectores ya construidos de la carretera y tramos para experimentar si eran propicios para los autos. Los socios piuranos unieron Piura y Chiclayo; luego otro raid se hizo entre Lima, Barranca y Lima, en 9 horas, por miembros limeños; como antesalas del raid que haría entre Lima y Piura José Bolívar a la cabeza de un grupo de socios, cubriendo el trecho de 1536 kilómetros en 50 horas. Por el Sur, los primeros raids permitieron unir Lima con Cañete, luego con Chincha, luego se hizo otro que unió Lima con Lomas, para que finalmente dos socios, Carlos Sutter y Luis Fernández, haciendo historia, hicieran la ruta Lima Arequipa de 1195 kilómetros de extensión en 35 días (TCP, 1925, I-1, pp. 15-16, 33-42 y 48-49; I-2, pp. 3137).

Al mismo tiempo que se hacían estos raids se hacían otros más específicos, como el de Cañete a Yauyos, para asegurar el camino que uniera este lugar costeño con la sierra limeña. La expedición salió el 19 de noviembre de 1925 de Lunahuaná en un Ford pilotado por Alejandro Chumpitaz e integrado además por el mecánico Ricardo Mavila, el fotógrafo Elías Acosta, el Teniente Gobernador del distrito de Zúñiga Víctor Candela -para quien seguramente era esencial abrir la ruta- y el jefe de la «arriesgada expedición» J. Mavila. Recorrieron diversos pueblos y comunidades campesinas hasta llegar a la ciudad de Yauyos, siendo recibidos con bandas de música y recorriendo las calles como auténticos héroes (TCP, 1925, I-5, pp. 52-55). Los raids de penetración se hacen cada vez más largos y en ese mismo año se hace uno entre Lima y Puquio, y luego otro que cruza la frontera, desde Puno a La Paz. Todos estos recorridos sin duda brindan valiosa información al Estado en plena construcción de caminos, pues quién si no los conductores de coches podían ofrecérselos.

Pero estos viajes exploratorios no solo eran de autos, también lo fueron de motocicletas, donde socios aventureros y amigos recorrían diversos lugares, trazando igualmente rutas y anotando obstáculos naturales para el desarrollo de deportes de aventuras. Por ejemplo en 1927, C. M. Gubbins y Guillermo Macher en un Douglas y un Rudge respectivamente, hicieron el recorrido de Lima a Lunahuaná (TCP, 1927, III-24/25, pp. 23-27). También se promovieron los viajes en bicicleta.

A la vez que se hacían estos, se organizaron las primeras carreras de autos, competiciones entre un número crecido de conductores cuyo fin no solamente era desarrollar el deporte de aventuras sino también consolidar las rutas y generar atención sobre los mismos. La primera carrera se organizó en 1924 en la ruta Lima Lomas - Lima, la segunda un año después en el mismo recorrido, y la tercera en 1926 en un circuito en Pachacámac. Era el nacimiento de los Gran Premio Nacional de Automovilismo. También se organizaron diversas carreras de motociclismo y de ciclismo. En 1926 se organizó un raid de ciclismo en la ruta Cuzco La Paz - Buenos Aires donde participaron los cuzqueños A. Pérez y J. Bolívar (TCP, 1925, I-5, p. 34; 1926, II-19, p. 35).

Un dato importante es conocer la fuerte concentración de automóviles en ciertos lugares del país, que explica también el protagonismo de ciertos grupos regionales en los primeros años del Touring. Según una cuenta de 1925 había en Lima 3360 autos y camiones y 5979 en todo el país. 550 se encontraban en La 
Libertad y Lambayeque, 350 en Cañete, 559 entre Ica, Chincha y Pisco. En todo el sur andino andino apenas existían 250 automotores. En 1927 existían 8856 automotores en todo el Perú, 5499 en Lima, Cañete tenía 325, Callao 427, Chincha 280, Cuzco 57, Arequipa 166, Trujillo 320. Huancayo 73, Huánuco 99, Pasco 53, Tarma 99. En 1929 existían 11906 autos y camiones en el país, ubicándose en el centro 225 vehículos (TCP, 1925, I-2, p. 28; 1927, III-33, p. 16; 1929, V-49, p. 46). Así pues el predominio de las elites locales y sectores medios en el sur chico, o litoral norte, con respecto a los contados lugares de la sierra lo debemos considerar en el análisis sobre los protagonistas de estas iniciales historias.

\section{Un Perú por conocer en la narrativa turística del Touring}

Por supuesto que los recorridos efectuados no solamente daban pie a diversos apuntes técnicos para las mejoras de los caminos, sino que también permitían que los mismos socios u otras personas recogieran apuntes turísticos de los lugares que visitaban, los sitios de interés y hablaran de los hospedajes y otros servicios que se ofrecían al viajero. Esto dio base a posteriores guías y una serie de documentos para el desarrollo turístico. El análisis de los mismos nos puede acercar a las miradas de estos viajeros, aunque habría que reconocer que escribían estos textos personas de distintos lugares del país y de variada condición social -desde clases medias hasta miembros de la élite limeña-.

No hay un descuido por ninguna región, si hacemos un análisis del periodo entre 1925 y 1930 en la historia del Touring. Al interés por promover el sur del país se unió el propio interés de los socios regionales sureños y de los intereses empresariales locales por posicionarlo en el imaginario nacional. Desde el primer número de su revista el Touring promovió el sur andino, con la crónica denominada «El Lago Titicaca», con datos útiles básicos, aunque encomendándoles a sus delegados en Mollendo, Arequipa, Puno o Cuzco toda la información pertinente, para construir un texto más orgánico (TCP, 1925, I-1, p. 26). Esto se da de a pocos, en los siguientes meses, con artículos meticulosos, cuyo conjunto nos describen casi toda la región. En «De Mollendo a Arequipa», se habla del puerto de Mollendo, su hermosa playa, sus dos malecones. Se menciona los hospedajes: el Hotel Ferrocarril, al frente de uno de ellos, o el Gran Hotel, a una cuadra más atrás. Este aporte descriptivo se mantendrá en los siguientes años cada vez que se hable del lugar. En Arequipa se arguye que uno se puede hospedar en cualquier hotel por la Plaza de Armas y de este modo, de manera confortable ir a las picanterías, pasearse entre los edificios, ir a Yanahuara, Tiabaya, Caima, Paucarpata, el Observatorio Astronómico de la Universidad de Harvard en Carmen Alto, al balneario de Jesús y como quien se va a Puno, detenerse en Yura (TCP, 1925, I-3, pp. 17-20; 1928, IV-36, pp. 7-10 y IV-37, pp. 41-45)». Las aguas termales de Jesús despiertan un gran interés, es un «centro del turismo nacional», entre el Misti y el pueblo de Paucarpata. Fray José Zavalaga fue el constructor de los baños y hay hotel y el baño tiene una piscina con vestuarios. El lugar está administrado por la Beneficencia y se recomienda por lo menos 4 semanas en el lugar (TCP, 1925, I-2, pp. 17-20). Yura «un bello rincón de reposo», con sus pozos y piscinas, también merece descripciones. «Este rincón es el Chamonix de Sudamérica» se asevera y se incluye un mapa elaborado por el propio Touring, comentando la existencia de dos hoteles allí: Barreda y el de las Termas de Yura, este último más grande (TCP, 1926, II-15/ 16, pp. 61-70). 
El viaje de Arequipa a Puno se hace en ferrocarril y la organización tiene vivo interés que el servicio vaya mejorando. Por ello no solo se acepta en su revista publicidad del Ferrocarril del Sur sino que sigue de cerca las inversiones que se realizan para tener vagones-dormitorios en la línea La Paz - Cuzco, que unido a la conclusión del ferrocarril de Bolivia con Argentina, permitirá el recorrido de Mollendo a Buenos Aires, haciendo incluso el viaje (de enlace por vapor) de Lima a Buenos Aires en 96 horas.

«La publicidad que tiene la revista del Touring es notable desde el inicio y los hubo de Lima, de lugares aledaños, del sur y de otros lugares del país. Ya en el primer número para el Callao se promociona, por ejemplo, el Rivera Palace Hotel de la Punta o el Leuro Hotel de Miraflores, ambos de A. Rodríguez Arias (TCP, 1925, I-1)». Como anunció el Ferrocarril del Sur, era un servicio rápido, entre Mollendo y La Paz, por el «Lago navegable más alto del mundo» que «merece ser conocido no solo por los extranjeros sino por todo Peruano» (TCP, 1925, I-4, p. 16; 1-5, p. 52 y I-7, p. 55).

Cuestión que aprovechó luego el ministro de fomento, Ernesto Souza, socio del Touring, en 1927, para hacer un recorrido Mollendo - Puno - Cuzco - Abancay, Coracora - Nazca y mostrar los horizontes que se abrían, por los enlaces, para muchos pueblos (TCP, 1927, III-28, p. 28).

En Puno, desde 1925 se comenta que la carretera Puno - Desaguadero está en plena construcción y se refieren al turismo por el lago Titicaca -desarrollado por la Peruvian Corporation- que permite recorrer en los vapores Coya y Yavarí, que ofrecen cuatro salidas de circunvalación al lago, y visitar Moho, Acosta, Huaycho, Carabuco, Pomata -con su bella Iglesia-, Juli -con su iglesia-, Acora y Chucuito. También se menciona que por tierra se puede visitar Sillustani y Atuncolla, y desde la ciudad de Puno la isla de Esteves, la isla de Romero, Totorani, y otros lugares. Ese año se esperaba que con estas promociones se animen los viajeros que desde Mollendo se dirigen en tren a Puno para continuar La Paz, a los festejos por el centenario de Bolivia, a detenerse en este departamento, que ofrecía incluso una Exposición Agrícola y ganadera para la ocasión (TCP, 1925, I3, pp. 9-16).

En el caso del Cuzco, al inicio el Touring reprodujo la Guía del Cuzco de Alberto Giesecke, recordándonos que se empleaba un día en el viaje de Mollendo a Arequipa -cinco horas, pero no se podía proseguir de inmediato-, un segundo día llevaba el recorrido de Arequipa a Juliaca, y un tercero a Cuzco, salvo que estando en Puno luego quiera uno dirigirse a Cuzco (le indica al turista no perderse cerca de Tinta, Raqchi, a 300 metros de la línea). Recordaba la guía los hospedajes en Mollendo, en Arequipa -recomienda el Macera, el Panamá y la Quinta Bates- en Juliaca -el hotel Rati, en la Plaza a cinco soles la noche-, en Puno -el hotel Ferrocarril, cerca de la estación, de la Peruvian; el Hotel Central a tres cuadras y el Hotel Nava, a cuatro soles-. Aconsejaba no preocuparse por la comida, pues el tren se detiene en las estaciones para hacerlo. Ya en Cuzco, aparte de guías y postales aconsejaba a los turistas interesados en objetos prehispánicos que «se encuentran antigüedades con facilidad, pero tiene el turista que cuidar mucho de conseguir algo genuino. Entre los más conocidos que poseen antigüedades en venta están César Lomellini y Cía, J. Olivera, Braulio Hermosa, Señora Vda. De Navarro y F. Caparó» (TCP, 1925, I-3, pp. 22-36). Van a pasar tres años antes de que se vuelva a hacer una descripción tan precisa de la ciudad y alrededores, y se hará dentro de la crónica El Perú Pintoresco y luego en la preciosa crónica Por las Tierras de Sur, un diario de viaje de Luis Varela y Orbegoso, 
donde se anota: «Es inexplicable cómo siendo el Cuzco un admirable centro de atracción para el turismo, hasta ahora nada se haya hecho para favorecer esa actividad, que al mismo tiempo que la riqueza hace el progreso de muchos pueblos, de lo que muestra evidente Italia y Suiza». Se queja que no hay hoteles en Cuzco, salvo el Hotel Colón, que sin embargo, a pesar de su ubicación «carece de muchas indispensables comodidades. Su propietario, el señor Pezo, se esmera en atender a los viajeros y por lo que se refiere al trato, el hotel resulta irreprochable». Lo mismo ocurre con el hotel Pullmann, aunque se entiende «que las facilidades que se obtienen son apenas las indispensables». Reconoce si que para ese año, 1928, la Peruvian está construyendo un hotel «a la moderna», aunque la obra avanza con lentitud. Pero una vez terminado será «el mejor beneficio que pueda recibir el Cuzco contemporáneo». Varela, que está de visita en el sur andino, luego prosigue en ferrocarril su viaje a Puno, donde sus amigos de la elite local, la familia Cárdenas Vega y el doctor Jorge Dulanto y Pinillos, intelectual puneño, lo pasean por el lago (TCP, 1928, IV-34, p. 17 y IV-36, pp. 39-48).

Aparte del sur andino, por cierto Lima y sus alrededores es objeto también de descripciones con afanes turísticos. Ya en 1925, en el segundo número de su revista, presentan la Pequeña guía del viajero en Lima, donde se describe los precios del tranvía Callao - Plaza San Martín, que permite movilizarse del puerto a la ciudad, para empezar el recorrido por el Museo Nacional, las iglesias como Santa Rosa y San Francisco, entre otras, insertando fotos, y recordando que siempre está la librería de Fernando y Emilio Rosay -socios además de la institución-, en la calle La Merced, para nutrirse de información. Describe igualmente Miraflores, Barranco y Chorrillos (El Club de Regatas) (TCP, 1925, I-2, pp. 43-35). Un año después presentan una Nueva Guía de Lima, donde incluyen dos hoteles donde hospedarse: Bolívar y Maury; museos a los que visitar: Nacional (en el paseo Colon, recinto de la Exposición Nacional), Arte Italiano, Bolivariano (Magdalena), Prado (particular), Arqueológico (Alfonso Ugarte), Alexander (particular), Brignardelo (particular) y el de la universidad de San Marcos (Parque universitario) (TCP, 1926, II-15/16, pp. 70-74). Parece, por otra fuente, también existía el llamado Museo de la Colonia (formado por el local de la Inquisición y la Casa de Perricholi). Luego publicará otras crónicas similares (TCP, 1926, II-21, pp. 9-28). En cuanto a lugares cercanos a Lima, existen finas crónicas que se publican en su revista como Chincha, lugar apropiado para hacer un viaje agradable, Turismo de Huancayo a Ica o Viaje de Cerro Azul a Asia, o de lugares arqueológicos como Paramonga o Pachacámac, este último texto a cargo de Horacio Urteaga (TCP, 1925, I-7, pp. 43-52 y I-8, pp. 49-50; 1926, II-19, pp. 1619; 1928, IV-34, pp. 27-32 y IV-37, pp. 9-14).

Pero, el Touring no se quedaba solo en la divulgación de lugares ya conocidos para sus socios y las familias de estos, sino que también daba a conocer otras regiones del Perú, dado que su interés -evidente en el año 1928, en el contexto de la próxima reunión en Lima del Segundo Congreso Sudamericano de Turismo- era construir una Guía General del Perú. Para la región norte un colaborador de la revista elabora en dos números sucesivos un Diario de un Turista, recorriendo la ciudad de Trujillo y la costa de La Libertad (TCP, 1925, I1, pp. 29-32 y I-2, pp. 38-42). Luego otro lo hará respecto a Piura, recordando que en la ciudad el hotel Colón, cuyo dueño es socio de la organización, es el único hospedaje apropiado para visitantes, con precios de tres a cuatro soles la habitación, pues los hospedajes Edén y Montero solo alquilan habitaciones cobrando 1.5 y 2.5 soles. Estas crónicas proseguirán en los años siguientes (TCP, 1926, II-11, pp. 14-15; 1928, IV-37, pp. 41-45). 
En el caso de la región central el Touring no solo recoge publicidad del ferrocarril central de la Peruvian que invita a los socios a conocer los distintos lugares siguiendo la ruta del tren, con un radio de conexiones por autos que incluye Ayacucho, Tarma o Chanchamayo; sino que recuerda que en los domingos de junio a noviembre hay un tren a Río Blanco ida y regreso con «dormitorio en el vagón en el hotel de Matucana». En un texto denominado una «Guía del itinerario de Camino Oroya a Puerto Yesup» -de Luis M. Praeli, publicado ese año en texto individual- se desarrolla los lugares de interés de la región y se anota que en Oroya existe el hotel Daneri, en Tarma otro hotel Daneri, más el Humberto y el Regional (Praeli, 1925; TCP, 1925, I-4, pp. 8-20).

Pero más importante que estos apuntes fundamentales serán los esfuerzos por publicitar el avance hacia el oriente, dar a conocer lo que las «zonas de montañas» poseen, relatos no exentos de visiones románticas pero también de mucho realismo de lo complejo de llegar a esos lugares. La entrada al fabuloso Pangoa, gracias a la labor meritoria de los frailes misioneros le impresiona, tanto que le dedica dos números a esta misión. Luego se describe un paseo de cuatro días por «la Montaña» con apuntes sobre La Merced, Tarma, Chanchamayo y el Perené. Señala que las obras en la vía central avanzan a paso regular, lo cual permitirá acercar la selva central a Lima, en particular Huánuco, al que le dedican sentidas crónicas, Visite Huánuco. Incluso empresas de la zona, como el Gran Hotel Fiume de esa ciudad, se publicitan en la revista. Más allá de la selva central, Iquitos llama la atención, reconoce que hay mucho por hacer pues la aviación se limita al servicio postal Lima - Iquitos, que sale una vez por semana pero se felicita que el empresario Víctor Israel no solo ha formado la delegación en Iquitos del TCP sino que además ofrece $25 \%$ de descuento en su vapores y lanchas para pasear por los distintos ríos del Amazonas, e incluso con su hija ha hecho el primer vuelo de pasajeros entre Lima e Iquitos, dando ejemplo de lo factible del transporte aéreo de personas. «En Iquitos en ese año 1928 E. Rodríguez publica una Guía de Iquitos. Comercial, Industrial y de propaganda, con fotos del estudio de Santiago Aspinwall, que bien puede insertarse en este clima. Un año antes, la editorial The West Coast Publishing Co. de Lima publica el albúm De Lima a Iquitos, con 250 fotografías, incluyendo el famoso Zoológico que H. Bassler tenía en Iquitos. En la ciudad había también varios estudios y personalidades que promocionaban la región a través de tarjetas postales con fotografías, como las de Bernardo Soto (La Serna \& Chaumeil, 2016, pp. 42, 196 y 211)». Su entusiasmo por la región de selva incluso lo lleva luego, en su Sección Turismo del año 1928 a la descripción «Expedición de Ecuador Praeli, de Paucartambo al Ene», desarrollando sus intereses -seguramente de la mano de los socios sureños, cuzqueños y puneños- por la selva sur. Ese mismo año publica Viaje de Lima a Madre de Dios, contribución de Antonio Cáceres a la Guía General del TCP en construcción, donde se narra las peripecias de un viaje exploratorio desde Juliaca por caminos tortuosos, posadas y hotelitos rústicos hasta llegar a Puerto Maldonado. Se reconoce que con sumo esfuerzo el gobierno está construyendo diversos caminos, como el de Huambutío a Alto Madre de Dios. A esto le seguirán los apuntes de un Itinerario para el viaje de Maldonado al Manu (TCP, 1926, II-21, p. 43; II-20, p. 19; 1927, III-31/32, pp. 27-32; 1928, IV-35, p. 13; IV-36, p. 24; IV-37, pp. 17-21; IV-39, pp. 1314; IV-42, pp. 21-23; 1929, V-52, pp. 35-39). 


\section{Las Guías del Perú y el Segundo Congreso Sudamericano de Turismo}

En el contexto del Segundo Congreso Sudamericano de Turismo (1929) la organización apresura la marcha para la creación de la Guía General del Perú. De hecho en su informe anual del año 1928 el presidente del TCP asegura que está lista la Guía de Piura, Guía General del Perú e Itinerario General del Perú. Como sea, la revista empieza a mostrar extractos de la futura Guía General Perú, con aportes específicos para el sur andino. Interesante es la relación de hospedajes que se muestra, notando -si contrastamos con la información previa que se tiene para algunas ciudades tres o cuatro años antes- como va evolucionando el sector. Mollendo, ha pasado de dos a cuatro hoteles: Ferrocarril (Peruvian), que cobra de 5 a 7 soles la habitación; Salerno; Pensión Privada Donelly, a una libra la noche; y la Pensión Sáenz. Se recuerda que en Mejía no hay hoteles ni comodidades, pero es la «playa de baños de la sociedad arequipeña». En Arequipa los hospedajes son la pensión Somocurcio, en la calle Sucre; y los hoteles Macera, Delgado, Gran Hotel en La Merced, Pensión Battes, Hotel Francia, Hotel Inglaterra (que es solo un alojamiento), Gran Pensión Bolívar, Hotel Internacional, Hotel Inglés y las pensiones Wagner y Hunt. En Juliaca está el Gran Hotel, con tarifas de 3 a 10 soles la habitación; y los hoteles Restaurant, Carpio y Americano, de 1 a 3 soles. En Puno hay servicio directo de vapor a Guaqui pero existen también los servicios ya narrados de vapores caleteros, por el norte y sur del lago. Los hoteles de Puno son el Ferrocarril (Peruvian), Bava, Extra Hotel y Velazco, así como la pensión Colón. En Sicuani prosiguen los mismos que años atrás: el Lafayette y el Ferrocarril (Peruvian). En el Cuzco está el Gran Hotel Colón, en la calle Heladeros, por el parque de Regocijo, frente a Prefectura, a cuatro soles la habitación. Luego el Hotel Pezo, en San Andrés; el Pullmann Club en San Agustín; y el Hotel Royal. En Urubamba: el Hotel Vargas, a 3 soles la noche, es el único existente (TCP, 1928, IV-39, pp. 25-34 y 45).

El esfuerzo por hacer la guía es notorio y en Hoteles del Perú unos meses después se muestra una lista lo más completa de hoteles y precios en el Perú, útil y necesaria para el viajero. Saltan los distintos hoteles existentes en Chancay, Huacho, Barranca, Supe, San Nicolás, Pativilca, Chosica -el Ferrocarril de la Peruvian, Royal, El Chalaco--, Cuzco, Urubamba, Abancay, Sicuani, Andahuaylas, anotando que en el camino entre Ayacucho y Andahuaylas no hay hoteles, excepto haciendas como las del señor Parodi, en cambio en Izcuchacha existe una pequeña fonda para almorzar y dormir con precios de 2 a 5 soles. Si existen hospedajes en Ayacucho, Huanta, Huánuco -allí están El Inca y el Fiuno-, en Cerro de Pasco -se menciona el Gran Hotel América-, Tarma -hoteles Bolívar, Humberto, y Regional-, en San Ramón -el Casabona-, Casma, Piura -el Colón, Edém y la Pensión Montero-, en Sullana, Tumbes -el Morón, Los Andes, Terranova y Oriente-, en Trujillo -el Challe y el Pedro-, Iquitos -Hotel Cosmopolita, al cual en otro número agregan El Malecón Palace, a 3 soles, el reciente Hispano Marroe y el Restaurant Ambos Mundos-, en Chincha -Gran Hotel Massa y el Cosmopolita-, en Mollendo, Arequipa -se anota el Delgado, Grand Hotel, Macera, Moderno y las pensiones Somocurcio, Bates, Bitmore, Wagner, Europea y Brunn-, en Moquegua, y finalmente en Locumba. Al año siguiente, 1929, actualizan esta lista y de allí en adelante procurarán periódicamente en su publicación mostrar esta Guía de Hoteles del Perú. Como novedad de la Guía de 1929, es que en Arequipa aparece el nuevo Hotel Sucre, recomendado, a 8 soles la habitación. En Cuzco ya está en funcionamiento el Hotel Ferrocarril, de la Peruvian, en la estación, con precios de 15 a 25 soles. En Huancayo, ferrocarril central, figura también otro Hotel Ferrocarril de la Peruvian, lo cual muestra las inversiones que está realizando la compañía de transportes en 
procurar lugares de hospedajes para sus pasajeros. Se precisa que en Ayacucho está el Hotel Imperial y en Huanta el Inca, en Trujillo el Astro y la Pensión europea. En Lima aparecen varios hoteles de primera -Bolívar, Maury, Plaza, Gran Hotel, Country, Bertolotto, Rivera- y de segunda -Gran Cardinal, Central, Comercio, Raymondi, España, Europa, Franco-Peruano, Leon’s, Terré, Colón, Los Andes y Pensión italiana--. A propósito de Lima, ya la revista ha publicado varias recomendaciones para la buena estancia del visitante en la ciudad, Lo que necesita saber el viajero a su llegada al Callao (TCP, 1928, IV-41, pp. 21-26; 1928, IV-42, pp. 1116; 1929, IV-52, pp. 33-34).

Momento final de este esfuerzo es sin duda la elaboración de un Calendario Turístico, con las actividades de interés en los 12 meses de año, en todo el país. Instrumento de información sin duda que corrobora el interés por servir a los propios socios y al país con nuevos insumos (TCP, 1930, VI-58, pp. 4-15).

Ciertamente había interés por desarrollar el turismo interno, particularmente entre los propios peruanos de allí su lema inicial «Conocer y hacer conocer el Perú, es contribuir a su grandeza»- pero también había interés de atraer flujos de turismo extranjero, contribuir a la labor que anteriormente en solitario la elite cuzqueña, la Peruvian, las empresas navieras, con desiguales intereses, estaban realizando. De hecho la revista se repartía en los consulados, hoteles y otras instituciones del mundo, gracias a las gestiones ante las autoridades de los socios. En Nueva York el Consulado, con su apoyo edita la revista Perú. Por ello Pedro E. Paulet, en un artículo, El turismo debe ser la primera industria nacional, desde Rotterdam hacía un llamado al Touring para seguir bregando en posicionar en el mundo al Perú pero también para exigir a las autoridades la solución de los principales obstáculos administrativos o naturales para conseguirlo. El progreso del sur era evidente, y no había como escatimarlo. Se construían más hospedajes, se mejoraban o construían caminos, el ferrocarril del sur avanzaba ya del Cuzco hacia Machu Picchu. Había alcanzado Ollantaytambo y Cedrobamba en 1928, y de allí se estaba enrielando hasta La Máquina, en el kilómetro 110. Todavía el viaje desde ese punto se hacía a lomo de bestia, pero pronto esto cambiaría, según la crónica Visiones de un viaje del Cuzco a Machupiccho. El ferrocarril lo construía el gobierno «deseoso de ofrecer al turista el máximo de posibilidades», pues el Cuzco «es un centro de turismo» y muchos norteamericanos llegan con cada vez más frecuencia, se dice en la crónica El Turismo en la altiplanicies andinas del Perú. Ello seguramente estaba en la base de la probable decisión de la operadora Agencia Cook, fusionada a la europea Wagon Lits, de establecer una oficina en Lima, como lo ocurrido con Expreso Villalonga, otra agencia marítima que promovía los viajes de recreación, que había nombrado a su representante en el Perú (M. F. de Cossío). «Efectivamente de la fusión de ambas surgió en 1927 la Wagons-Lits Cook, que existió hasta la decada de 1970. Dominaban el mercado europeo como la American Express dominaba el mercado norteamericano. En 1928 apareció Exprinter Travel Service, una agencia al por mayor, que no entró en la competencia minorista (Khatchikian, 2000, p. 228)». Así pues, se pensaba, se podría extender al Perú los flujos de turistas europeos (que podrían ahora llegar por la Wagon) y de norteamericanos. «Todo hace presuponer que (1929) será, pues, un año fecundo para el desarrollo del turismo en el Perú» se afirmaba a fines de 1928 (Memoria del Segundo Congreso Sudamericano de Turismo, 1929, II: 270; TCP, 1928, IV-44, pp. 19-24, IV-45, pp. 5-6 y 19; 1929, V-55, p. 43; 1930, VI-61, p. 47; VI-62, pp. 33-36). 
Este optimismo también se basaba en lo que se estaba haciendo en otros lugares del país, que se pensaba igualmente, repercutiría en el desarrollo del turismo nacional e internacional. Entre Lima e Iquitos no solo había conexión aérea postal desde el 3 de enero de 1928 sino que ya se daban los viajes de pasajeros: se llegaba en automóvil desde La Oroya hasta San Ramón y desde allí en escalas se iba por vía aérea a Puerto Bermúdez, Masisea y finalmente a Iquitos. También había viajes desde Iquitos o San Ramón a Moyobamba y a Yurimaguas. Por otro lado había tráfico aéreo entre Lima y Arequipa desde 1929 y Panagra conectaba desde Panamá por el norte y Santiago por sur, diversas ciudades del norte y sur peruanos (TCP, 1929, V-49, p. 46 y V-52, p. 41; 1930, V-59, p. 23). La ilusión de un buen año se afianzaba igualmente en que se realizaría el Segundo Congreso Sudamericano de Turismo, que reuniría a delegaciones de los Touring de varios países, vendrían muchas otras delegaciones y se pensaba realizar con ellos un crucero turístico al surandino y al Chanchamayo.

Sobre esta base, para el Congreso la institución no solo publicitó en su revista valiosos artículos de guías para conocer el Perú -véase Los medios de transportes en el Perú ¿Cómo viajar al Perú, el país de los Incas?, Las mejores rutas del turismo peruano. La ruta del ferrocarril del Sur y caminos adyacentes, Lima, the capital of the Republic, Lima - Chanchamayo, emociónate ruta del turismo o Las estaciones termales en el Perú- sino que se editaron los libros El Perú Antiguo de J. C. Tello, El Cusco de Darío Eguren de Larrea, La Red Nacional de Carreteras de E. Diez Canseco y F. Aguilar Revoredo, y Desde el mar hasta las selvas de J. G. Otero. Por su lado Luis M. Gamio publicó su Guía itineraria del Perú: vías de comunicación y turismo (1929) y César Zapatel, a nombre del Touring Club Peruano, Viabilidad y turismo (1929), donde presentó una guía de caminos en el marco de la Guía General del Perú, Guía del Sur, de Piura, de Trujillo que se estaban confeccionando y que hemos visto se están publicando parcialmente.

La de Zapatel quiso ser una guía de caminos, que superara a las otras guías, por lo que hizo una descripción departamento por departamento de los caminos y los atractivos turísticos, aunque no se mencionó a los hospedajes, tal vez por que existían los otros documentos para aquello. Por sus páginas pasaron diversos atractivos que localmente se conocían y que deseaban que tuvieran un reconocimiento nacional -por ejemplo en Ica la laguna de Huacachina, que tenía un flujo de visitantes que desde mucho tiempo atrás frecuentaban sus aguas consideradas medicinales- pero también había comentarios, típico de una época de desprecio racial, como la descripción que se hizo de un niño de Huancayo. Sin embargo, existen muchos comentarios realistas sobre la realidad vial del país: las carreteras nacionales no terminan de unir todavía todo el país; hay desconexiones en la región sur, pues de Lima hasta Chala hay continuidad de la carretera costanera, pero luego hay desconexiones dentro del departamento de Arequipa y entre este con Puno y con Cuzco, aunque curiosamente no entre Puno y Cuzco, donde hay una vía continúa; desconexiones también existen en la región norte, y de la costa de esta con la sierra; igual que desde Lima no hay una vía continúa hasta la sierra central, aunque al interior de la región -en el valle del Mantaro, por ejemplo- sí existe esa continuidad. Aunque hay diversos caminos a la selva, de la sierra central a Chanchamayo los autos deben pasar varios puentes colgantes. De todas maneras se anuncia la terminación de la carretera Lima - Canta - Cerro de Pasco, que se inauguró en el marco del Congreso de Turismo en Lima, y que tenía como deber ayudar parcialmente a superar estos problemas. 
El Primer Congreso Sudamericano de Turismo había sido en Buenos Aires, en 1928, habiéndose formado la Federación Sudamericana de Turismo integrada por los Touring Club de los países de la región -Argentina, Uruguay, Paraguay, Chile, Brasil, Perú, Ecuador, Colombia, Venezuela y Panamá-. Allí se acordó apoyar los esfuerzos de vialidad que se realizaban en el continente, promover las facilidades a los turistas, facilidades al internamiento de autos, facilidades de trámites administrativos, e incluso se abogó por no usar pasaporte entre los visitantes de los países de la región. Se abogó también por una carretera sudamericana, desarrollo de oficinas de información, cartas turísticas sudamericanas, la conservación y defensa de los recursos naturales y arqueológicos, descubrir otros, así como la reglamentación y estímulos a la construcción de hoteles, en particular hoteles de turistas. Parte de esta plataforma había sido promovida por el Touring Club Argentino, la gestora de esta iniciativa, a lo largo de la década (Piglia, 2008, pp. 55-59). El Congreso, dentro del cual la delegación del Touring peruano tuvo destacada actuación, planteó la siguiente reunión en Lima en 1929. Luis Dibós, Fernando Carbajal y Ernesto Diez Canseco se lanzaron a la organización del mismo, planteando que aparte de discutir en profundidad lo revisado en Buenos Aires, el acontecimiento debería ayudar a un mayor compromiso en el país, construyendo un Palacio del Turismo para la ocasión, creando una oficina de información turística, así como empezar a desarrollar la infraestructura básica a plenitud -ferrocarriles, sitios de interés- (Memoria del Segundo Congreso Sudamericano de Turismo, 1929, I, pp. 7-23). Se insistiría en lo mismo, posteriormente, recomendando crear un par de oficinas de turismo en el muelle del Callao -hubo que esperar a la década de 1940 y la labor de la Corporación Nacional de Turismo para ver la realización de aquello- (Memoria del Segundo Congreso Sudamericano de Turismo, 1929, II, p. 13).

En los preparativos del Congreso la participación del gobierno fue activa, pues se consideraba prioritario apoyar este esfuerzo. Para ello enviaron representantes al evento -existe un Departamento de Turismo en el Ministerio de Fomento-, destinó recursos económicos para el éxito del mismo, se dieron facilidades administrativas para el ingreso de las delegaciones y se repartieron medallas conmemorativas en el evento. El comité organizador previó, entre las actividades a realizar en Lima, la visita al Museo de Arqueología, del cual Julio C. Tello, miembro del Comité, era también su director. Asimismo una visita a Pachacámac, sugerido igualmente por el mismo Tello, quien aprovechó para, a través de la organización, pedir al Estado sumas de dinero para la restauración de Pachacámac, además de conseguir detener la labor de un concesionario existente allí, que con autorización y ayuda de soldados andaba buscando tesoros y estaba destruyendo estructuras del sitio -algo que en sus argumentaciones mostraba como muy frecuentes y que merecía su constante intervención-. Los fondos para restauración fueron para mejorar las terrazas y así organizar una exhibición de vestidos, recreando para los invitados una peregrinación ritual. Para estos vestidos se utilizaría los existentes en el museo de arqueología (Memoria del Segundo Congreso Sudamericano de Turismo, 1929, I, pp. 77-78, 160-162 y II, p. 274).

También se organizaron excursiones al territorio nacional. Se pensó en una a Chanchamayo y otra al Cuzco, cuando de regreso de Lima los invitados (mayormente argentinos), que venían con sus familias, decidan hacer un viaje masivo, desembarcar en Mollendo, yendo por ferrocarril a Cuzco y luego Puno, para continuar por Bolivia hasta Buenos Aires, en el sistema ferroviario interconectado. Para ello el comité organizador averiguó sobre las facilidades, en Arequipa se escogió como lugar para descansar el recientemente construido Hotel 
Sucre (por encima del de Somocurcio y el Wagner) y en Cuzco el recientemente inaugurado Hotel Ferrocarril, de la Peruvian. En Puno el Hotel Ferrocarril del lugar, cuando no se duerma en los vagones. Se hizo una guía de Cuzco y otras ciudades, facilitando el gobierno fotos y vistas aéreas de Lima, Arequipa, Cuzco, Cañete y otros lugares (Memoria del Segundo Congreso Sudamericano de Turismo, 1929, I, pp. 157-158). En todo caso este retorno dependía de los invitados. En Lima el Touring organizó el viaje a Chanchamayo en autos, partiendo de La Oroya a Tarma en 7 autos, hospedándose en el Hotel Bolívar de Tarma, de allí a Naranjal, San Ramón, La Merced hasta el Perené (Memoria del Segundo Congreso Sudamericano de Turismo, 28; TCP, 1928, IV42, p. 45; 1929, V-54, pp. 13-32 y 41-44, V-55, pp. 13-21 y 43). Se hizo una filmación del recorrido, a cargo de Guillermo Garland Higginson (La Serna \& Chaumeil, 2016, p. 105).

¿Cuál fue el resultado práctico de esta reunión? Aparte de repartirles una serie de materiales turísticos, como los vistos, a los asistentes y conseguir «venderles» el atractivo por el país, se hizo una declaración donde se reiteró en esencia lo planteado un año antes en el Primer Congreso Sudamericano (Memoria del Segundo Congreso Sudamericano de Turismo, 1929, II: 12). Lamentablemente, la crisis económica mundial que estalló de inmediato afectó la posibilidad de nuevas reuniones de la Federación Sudamericana de Turismo, siendo reemplazada en el contexto de la VIII Conferencia Panamericana por la Primera Conferencia Interamericana de Turismo, un espacio interamericano de los años 30.

\section{Las políticas turísticas en la esfera pública}

A veces erramos en la apreciación que tenemos sobre políticas públicas y turismo. Como se ha podido constatar hay un interés creciente del Estado por el desarrollo del turismo en esos años, y en ese proyecto hay mucha colaboración con diversos grupos de interés. El Estado, desarrollando su política vial entiende la importancia de que las personas -dada la emergencia de las clases medias urbanas- conozcan el país y mira con beneplácito la creación del Touring Club Peruano. Como hemos visto apoya el Segundo Congreso y se muestra receptivo a las iniciativas de esta entidad para la mejora del flujo turístico extranjero hacia el Perú. De hecho por aquella época se había llevado a cabo una Conferencia Técnica Nacional de Carreteras, donde también el sector privado y público -como en Argentina con el Congreso Nacional de Vialidad de 1922 y ante todo por el influjo originado en el Primer Congreso de Carreteras de 1925 y por la Conferencia Interamericana de Carreteras, que fue el marco para hacer realidad el acuerdo panamericano de desarrollar una carretera hemisférica- confrontaron pareceres sobre la vialidad en el país. También apoyó el desarrollo de la navegación aérea y vio sus posibilidades en el turismo.

Pero muchas otras iniciativas asociadas hubo en estas relaciones, por ejemplo, cuando acudió el Touring por aquellos años al pedido del Estado para señalizar la carretera costanera y así mejorar la circulación vehicular. Esto se empezó en 1926, en el tramo entre Lima y Cañete (hasta Cruz de Hueso). Igualmente, debido a que en 1929 el gobierno había dado un reglamento para los establecimientos destinados al hospedaje de viajeros, en febrero de 1930 el Touring hizo un llamado para que los municipios creen una inspectoría de hoteles, y se consiga una mejora en la calidad de los servicios. Algunos municipios pequeños acudieron al apoyo de esta iniciativa, consiguiendo la instalación de dicha inspectoría de hoteles (TCP, 1926, II-19, p. 19 y II-24/25, 1929, 
V-55, pp. 15-16; 1930, VI-59, p. 23). El Touring, así como en otros países, entendió que la acción del Estado era fundamental para orientar con más determinación en los años siguientes la labor de promoción y regulación turística. En los distintos países del mundo, entre fines de la década de 1920 e inicios de la siguiente, se van dando estas definiciones. En América además influyen las Conferencias Panamericanas que urgen a una intervención de los Estados (Piglia, 2008, p. 55). En esa lógica en 1928 el ilustre puneño Emilio Romero, en su artículo Legislación sobre el turismo y el Perú publicado en la revista institucional del Touring planteó que en el Perú se estableciera un Consejo Nacional de Turismo integrado por el Ministerio de Fomento, el mismo Touring y la Junta Arqueológica Nacional, entre otros. Era pues el inicio de la discusión para el establecimiento de una entidad específica que desarrolle una política turística en el Perú (TCP, 1928, IV-42, p. 30).

Es cierto que la crisis económica de 1929 y la postrera caída del gobierno de Augusto B. Leguía en agosto de 1930 enturbiaron las promesas de un rápido despegue turístico. Con la caída del régimen, la Junta de Gobierno presidida por Luis M. Sánchez Cerro derogó de inmediato la impopular ley de Conscripción Vial, que tanto abuso había provocado entre la población humilde. El Touring no tuvo más remedio que estar de acuerdo con el fin de la ley de vialidad, aunque pidió que no se dejen de construir carreteras y que se mejore el sistema impositivo, para lograr un mejor desarrollo del sector automotriz. Es decir trató de evitar la paralización de las obras públicas y pidió -en consonancia con los acuerdos del Segundo Congreso- la reducción de impuestos y trabas administrativas para favorecer el aumento del parque automotor. En un balance de la memoria 19281930, aparte de todo lo que había hecho, reconoció que no se había logrado interesar todavía al gobierno en un autoridad nacional del turismo.

Empero, no es tan cierto que hubo una parálisis absoluta en la evolución de una acción pública turística. Sea por sus presiones, sea por el propio interés gubernamental, lo cierto es que a las pocas semanas el gobierno les confía llevar las cuentas de la inmigración y la propaganda en el exterior del Perú, permitiendo que el Touring continuara manteniendo su política de difusión del Perú. En la Exposición de Turismo en Londres de 1930 estuvieron con un stand presentando mapas y otros materiales de interés. Por otro lado, tampoco es cierto que se produjo una parálisis total en las obras viales (TCP, 1930, VI-66, pp. 1-2 y VI-68, p. 1).

Así pues, debemos tener cuidado a la hora de plantear la inexistencia de intereses por el desarrollo de políticas públicas a favor del turismo. Es cierto que hay un fuerte protagonismo del sector privado en su promoción, pero tampoco hay una inoperancia pública. E incluso se está procurando que este gane un mayor protagonismo. 


\section{Conclusiones}

Como se ha podido apreciar, en esta década de los años veinte, se produjo un cambio acelerado para las condiciones del desarrollo turístico en el Perú. La actividad del Touring Club Peruano, la acción del Estado a través de sus normas y sus obras -viales, ferrocarril a Machu Picchu, apoyo económico para la promoción-, el desarrollo de inversiones privadas -hospedajes, mejora del servicio ferroviario, llegada de operadores internacionales- permiten demostrarnos que a pesar de las dificultades geográficas, de lo complejo del contexto político, de los problemas estructurales sociales y económicos del país se están desarrollando actividades de turismo local y están llegando flujos de turistas foráneos al sur andino. Pero por sobre todo, el auto y los caminos han acercado, a los propios peruanos, diversos lugares de interés, permitiendo una democratización del acceso al turismo para muchas personas, aunque todavía estas sean de sectores altos y las emergentes clases medias urbanas. Por otro lado, el turismo ha pasado en la práctica de no existir a estar presente como tema público, ha pasado a estar en la agenda del gobierno y a través de los medios se habla de él. Sin duda, muchas personas y entidades han contribuido a ello para que gane lugar en el espacio público y la opinión. No solo en la acción gubernamental sino que en la de varios actores de la sociedad -como los empresarios, instituciones o las elites regionales locales- conscientes de su trascendencia.

\section{Referencias}

Ahora (diciembre de 1982). El Patriarca de la Hoteleria Peruana. Revista Ahora, Lima.

Ballent, A. (2005). Kilómetro Cero: la construcción del universo simbólico del camino en la Argentina de los años treinta. Boletín del Instituto de Historia Argentina y Americana Dr. Emilio Ravignani, 3(27), 107-139.

Boyer, M. (2002). El turismo en Europa, de la edad moderna al siglo XX. Historia Contemporánea, 25, 13-31.

Cosio, J. G. (1912). Una excursión a Macchupiccho, ciudad antigua. Revista Universitaria, 2.

Cosio, J. G. (1924). Cuzco, the historical and monumental city of Peru: travelers'guide. Lima: Incatezca.

Cossio del Pomar, F. (1922). Historia Crítica de la pintura en el Cuzco. Cusco: Imprenta H. G. Rozas.

Dadon, J. R. (2005). Historia ambiental y turismo en la costa bonaerense. De playas, vacaciones y ecología. Todo es Historia 450, 54-62.

Dargent, E. (s.f.). Los hoteles de los Wiese. Lima: pro-manuscripto.

El Comercio (1915 - 2015). El Comercio. Lima.

Frisancho, J. (1931). Del Jesuitismo al Indianismo. Cuzco: Talleres Tipográficos Imperial.

García, U. (1922). La ciudad de los Incas. Cuzco: Imprenta H. G. Rozas.

García, U. (1925). Guía histórica-artística del Cuzco. Lima: Imprenta Garcilaso.

Giesecke, A. (1924). Guía del Cuzco. La Meca de América del Sur. Lima: Imprenta Garcilaso.

Giuntini, A. (2002). Ferrocarriles y turismo en Italia desde los inicios del ochocientos hasta la introducción de los «trenes populares» en la época fascista. Historia Contemporánea, 25, 101-123.

Gordon, B. M. (2002). El turismo de masas. Un concepto problemático en la historia del siglo XX. Historia Contemporánea, 25, 125-156. 
Harp, S. L. (2002). The Michelin Red Guides: Social Differentiation in Early Tweentieth Century French Tourism. En R. Koshar (ed.), Histories of Leisure. Nueva York y Oxford: Berg.

Khatchikian, M. (2000). Historia del Turismo. Lima: Universidad de San Martín de Porres.

La Serna, J. C., \& Chaumeil, J. P. (2016). El bosque ilustrado. Diccionario histórico de la fotografía amazónica peruana (1868-1950). Lima: CAAAP-IFEA-Centro EREA-LESC/CNRS-PUCP.

La Sierra (abril de 1927). La Sierra. pp 19-22. Lima.

Larco Herrera, R. (ed.) (1934). Cusco Histórico. Homenaje a la ciudad de todos los tiempos en el cuarto centenario de su fundación española. Lima: La Crónica y Variedades.

Loayza, A. (editor). (2016). La independencia peruana como representación. Historia, memoria, y escultura pública. Lima: Instituto de Estudios Peruanos.

López, Y. (2004). El Cusco, paqarina moderna. Cartografía de una modernidad e identidades en los Andes peruanos (1900-1935). Lima: Universidad Nacional Mayor de San Marcos y CONCYTEC.

Memoria del Segundo Congreso Sudamericano de Turismo (1929). Memoria del Segundo Congreso Sudamericano de Turismo. Lima: Empresa Editora Cervantes.

Mundial (12 de diciembre de 1924). Mundial. Lima.

O'Connell, S. (1998). The car in British society: class, gender and motoring, 1896-1939. Manchester: Manchester University Press.

Orrego, J. L. (2014). ¡Y llegó El Centenario! Los festejos de 1921 y 1924 en la Lima de Augusto B. Leguía. Lima: Titanium editores.

Pastoriza, E. (ed.). (2002). Las Puertas al Mar. Consumo, ocio y política en Mar del Plata, Montevideo y Viña del Mar. Buenos Aires: Universidad Nacional de Mar de Plata, Biblos.

Piglia, M. (2008). La incidencia del Touring Club y del ACA en la construcción del turismo como cuestión Pública (1918-1929). Estudios y perspectivas en turismo, 17, 51-70.

Piglia, M. (2008a). Viaje deportivo, nación y territorio. El Automóvil Club Argentino y los orígenes del Turismo Carretera. Argentina, 1924-1938. Nuevo Mundo Mundos Nuevos [Online]. doi: 10.4000/nuevomundo.40923. Recuperado de http://nuevomundo.revues.org/ 40923

Pinilla, M. (1928). Las piedras de El Cuzco. Lorca: Agustín Moya.

Romero, E. (1929). 3 Ciudades del Perú. Lima: Imprenta Torres Aguirre.

Touring Club Peruano (1925 - 1935). Revista Touring Club Peruano. Lima.

Valcárcel, L. E. (1925). De la vida incaica. Algunas captaciones del espíritu que la animó. Lima: Garcilaso.

Valcárcel, L. E. (1927). Tempestad en los Andes. Lima: Biblioteca Amauta.

Valcárcel, L. E. (1934). Cuzco, capital arqueológica de Sud América. Lima: Banco Italiano.

Variedades (20 de diciembre de 1924). Revista Variedades. Lima.

Walton, J. (2002). Aproximación a la historia del turismo en el Reino Unido, siglos XVIII-XX. Historia Contemporánea, 2(25), 65-82.

Zapatel, C. (1929). Viabilidad y turismo. Lima: La editorial. 